\section{Options for Online Undergraduate Courses in Biology at American Colleges and Universities}

\author{
Alison K. Varty* \\ Biology Department, College of the Siskiyous, Weed, CA 96094
}

\begin{abstract}
I aimed to document the online undergraduate course supply in biology to evaluate how well biology educators are serving the diverse and growing population of online students. I documented online biology course offerings in the 2015-2016 academic year at 96 American colleges and universities. I quantified differences in variety, extent, and availability of courses offered by different kinds of academic institutions and characterized 149 online biology courses offered. Although there was no relationship between an institution's enrollment size and any measure of its online biology offerings, I found significantly more online biology course options at 2-year public compared with 4-year public and 4-year private schools. Courses offered for nonmajors, including students pursuing healthcare-related degrees, were three times as common as those intended for biology majors, who were more likely to be offered hybrid courses with face-to-face laboratories. These data indicate some deficiencies in online biology course options; options for students majoring in biology are limited at all types of institutions examined with a minority of 4-year institutions having any online options in biology. Significant investment of institutional resources in faculty training and technological support are necessary to develop online biology courses that will benefit a larger student population.
\end{abstract}

\section{INTRODUCTION}

Online education is transforming the landscape of American higher education. From 2000 to 2008, the percentage of students taking at least one online course increased from 8 to 20\% (Radford, 2011), and by 2012, this statistic had increased to 33.5\% (Allen and Seaman, 2013). College and university faculty and administrators project continued growth in online offerings into the future (Kim and Bonk, 2006; Allen and Seaman, 2014).

Several factors appear to be driving this growth. Online courses are popular with college and university administrators, because they can decrease operating costs. For example, an institution lacking funds to build more classrooms and/or parking facilities to accommodate growing enrollments can meet the demand with online courses (Howell et al., 2003; Dziuban et al., 2004; Mayadas et al., 2009; Brown, 2011). Online learning can also reduce the cost of running a course (Twigg, 2003; Vaughan, 2007). Additionally, since the current supply of online courses is a diverse market, and students are shopping around for courses offered by thousands of institutions (Howell et al., 2003), increasing online course and program offerings can open an institution up to new student populations and increase enrollments (Moloney and Oakley, 2010; Brown, 2011). Conversely, not offering online courses could drive students into other institutions' online courses, thereby decreasing an institution's enrollment (Howell et al., 2003). Finally, strong student demand appears to be driving growth for online education. According to Garrett (2007), 53\% of people who claimed they were interested in pursuing postsecondary education in the next 3 years indicated their preferred mode of delivery would be totally online or an equal balance between online and on-campus instruction.
Jeff Schinske, Monitoring Editor

Submitted January 19, 2016; Revised March 31, 2016; Accepted April 23, 2016

CBE Life Sci Educ December 1, 2016 15:ar58

DOI: 10.1187/cbe.16-01-0075

*Address correspondence to: Alison K. Varty (varty@siskiyous.edu).

(c) 2016 A. K. Varty. CBE-Life Sciences Education (c) 2016 The American Society for Cell Biology. This article is distributed by The American Society for Cell Biology under license from the author(s). It is available to the public under an Attribution-Noncommercial-Share Alike 3.0 Unported Creative Commons License (http:// creativecommons.org/licenses/by-nc-sa/3.0).

"ASCB®" and "The American Society for Cell Biology $\AA^{\circledR}$ are registered trademarks of The American Society for Cell Biology. 
It is important to meet student demands for online courses. Online learning is more convenient for some students and makes accessing higher education a possibility for others, as it creates educational opportunities that are free of time and geographic constraints (Geith and Vignare, 2008). Additionally, the typical online student population includes higher than average percentages of nontraditional students, women, and minorities (Radford et al., 2015). Thus, online offerings help institutions attract and educate a more diverse student population.

Not all types of academic institutions are embracing online education equally. Currently, students attending public institutions are more than twice as likely as students at private colleges to be taking some of their courses online (Ginder and Stearns, 2014). Among the private colleges, online enrollments increased dramatically at nonprofit institutions while declining sharply at for-profit institutions from 2012 to 2013 (Allen and Seaman, 2015). This suggests that future demand for online courses will be met by public institutions and, increasingly, by private nonprofit institutions. There also appears to be a positive relationship between the size of an institution and the likelihood that it offers online courses (Parasad and Lewis, 2008). While nearly all institutions with more than 15,000 students offer online courses, approximately one-third of those with fewer than 1500 students do not offer any online courses (Allen and Seaman, 2014).

Growth of online offerings has not been equal in all academic disciplines. Science, technology, engineering, and mathematics (STEM) students appear to have fewer online course and degree options than those studying other disciplines. During the 2007-2008 academic year, students enrolled in natural science, mathematics, and agriculture programs of study were $30 \%$ less likely to be taking an online course and $75 \%$ less likely to be enrolled in an online degree program than their peers in other disciplines (Radford, 2011). In 2007, online programs in engineering were only offered at $16 \%$ of American colleges and universities, whereas programs in psychology and business were nearly twice as common (Allen and Seaman, 2008). Given high student demand for online learning and unique demographics of online students, national efforts to increase the number of STEM graduates (National Academies of Science, Engineering, and Medicine, 2007) and promote diversity within STEM disciplines (National Academies of Science, Engineering, and Medicine, 2011) may benefit from increased online STEM offerings.

Laboratories are a common barrier to offering STEM classes online (Kennepohl and Shaw, 2010; Jeschofnig and Jeschofnig, 2011). Several alternatives exist to overcome this obstacle, including: online virtual or simulated laboratories; laboratory videos; and hands-on distance activities such as kitchen laboratories, in which students set up and conduct experiments at home using household items, or laboratory kit activities, which are mailed to students and include equipment, materials, and protocols that more closely mirror traditional laboratory experiences. Each of these options has drawbacks. Although virtual laboratories can be useful in many educational contexts, they do not provide students with the same tactile experiences and opportunities to learn discipline-specific techniques and operate related equipment. Furthermore, organizations such as the American Chemical Society (ACS) and the National Science Teacher's Association (NSTA) do not consider virtual laborato- ries equivalent to traditional laboratory experiences (NSTA, 2007; ACS, 2009, 2015). Kitchen laboratories and laboratory kits may cost students more than the laboratory fees they would pay in face-to-face courses and introduce safety and liability issues (Jeschofnig and Jeschofnig, 2011). Additionally, some argue that, due to equipment and materials cost and safety limitations, many of the hands-on distance laboratory activities lack the rigor of traditional experiments and can be useful only for illustrating certain processes (Reeves and Kimbrough, 2004; Lyall and Patti, 2010; Jeschofnig and Jeschofnig, 2011). Students have noted that distance hands-on activities take more time to complete (Lyall and Patti, 2010), which may be due to the lack of student-to-student interaction and the absence of an instructor for guidance (Kennepohl, 2007).

Hybrid courses offer a solution in which students can fulfill the laboratory requirement of science courses face-to-face while engaging with other course content online. It is unclear, however, how frequently this option is available to science students. Hybrid courses, those that include between 30 and 79\% online delivery, are not as common as fully online courses, in which more than $80 \%$ of the content is delivered online (Allen and Seaman, 2008); while $45.9 \%$ of undergraduate institutions offered at least one hybrid course, $55.3 \%$ offered at least one fully online course in 2004 (Allen et al., 2007). Hybrid courses may be less appealing to administrators and students, because their face-to-face class requirements may limit student enrollment.

One of the major goals of my research was to document online course options in biology, as this information is not available. A search of Peterson's Online Schools database revealed that only 15 American institutions offered online undergraduate degrees in biology (Peterson's, 2015). Although online biology program options are limited, a higher than average percent of students studying in healthcare fields take online courses (Radford, 2011). Thus, healthcare program prerequisites or requirements may be a significant portion of the online offerings in biology, although this has not been documented.

A distinction among biology courses offered at many colleges and universities is whether those courses are geared toward nonmajors who need to fulfill general education requirements or students majoring in biology. Nonmajors biology courses may be the only academic exposure a student has to a scientific discipline and, as a result, are typically more focused on promoting general scientific literacy and highlighting the social relevance and application of scientific knowledge (Sundberg and Dini, 1993; Wright, 2005). Appealing courses offered primarily for nonmajors can also help biology departments increase their student contact hours and can inspire students to declare the major (Klymkowsky, 2005). In contrast, courses offered for biology majors are generally part of an extended sequence of study within the discipline and include greater depth of coverage of discipline-specific content that prepares students for advanced study in biology (Sundberg and Dini, 1993; Klymkowsky, 2005). As a result of the differing emphases and goals of biology courses geared toward majors and nonmajors, their likelihoods of being offered online may differ, although this too has yet to be studied.

Knowing the current landscape of online offerings in biology can illustrate 1) how biology online offerings differ from the rates of online offerings in general; 2) which types of courses 
biology departments are having success offering; and 3) deficiencies in biology online offerings that may be barriers to student access. My goal was to create a baseline understanding of our current online offerings in biology at American colleges and universities. Specifically, I aimed to

1. Document how the diversity and availability of online biology courses differ at different kinds of American colleges and universities, including 2-year public, 4-year public, and 4-year private institutions;

2. Document which kinds (fully online vs. hybrid, majors vs. nonmajors, laboratory vs. nonlaboratory) of undergraduate biology courses American colleges and universities are offering online; and

3. Make recommendations for growth in future online offerings in biology.

\section{METHODS}

\section{Data Collection}

I generated comprehensive lists of 2-year public, 4-year public, and 4-year nonprofit, private (hereafter referred to as "4-year private" colleges) American colleges and universities using the National Center for Education Statistics (NCES) Integrated Post-Secondary Education Data System (IPEDS), which included 1020, 701, and 1596 institutions, respectively (NCES, 2015). Next, I used a random-number generator to randomly select 16 colleges and/or universities from each of the three categories. For the selected institutions, I searched the online course schedules for undergraduate offerings in biology or biological sciences in the Fall 2015 semester or quarter between August 20 and September 23, 2015. I repeated this selection process for the Spring 2016 semester or Winter and Spring quarters between February 26 and March 3, 2016. If the selected institution did not offer undergraduate courses in biology or biological sciences or if the course schedule was not available online, I randomly selected another institution from the list. I recorded the number and kinds of institutions that did not meet these criteria in Spring of 2016, but not Fall of 2015. For each institution surveyed, I estimated the full-time equivalent (FTE) undergraduate enrollment for academic year 20122013 using the IPEDS database.

When searching the course schedule for an institution, I noted the total number of unique undergraduate biology courses and number and titles of each unique undergraduate course offered online or hybrid in Fall of 2015 or Spring of 2016. When an institution listed lectures and corequisite laboratories separately, I counted these as one course. Aligned with Allen and Seaman's (2008) definitions of online versus hybrid courses described in the Introduction, I denoted online courses as those that were described as such and did not have regular class times and rooms. Hybrid courses were those that were noted as such or that had one component of the course listed as online but other components (e.g., laboratory sections) only offered face-to-face. I also denoted as hybrid courses those that were listed as online courses but had reduced regular meetings times compared with face-to-face courses. Additionally, I counted the total number of undergraduate biology sections offered and the number of biology undergraduate sections that were offered fully online or hybrid online, counting laboratory and lecture sections separately.
I documented additional information about the undergraduate courses that were being offered online or as hybrid-online courses. By reading the descriptions in the course catalogue, I determined whether the courses included laboratory components or were lecture-only credit hours. Additionally, I determined whether the courses were intended for biology majors or nonmajors. If the catalogue listing indicated the course was intended for biology majors, if it was listed as part of the institution's biology major, or if it required the institution's introductory biology course(s) for biology majors as a prerequisite, I counted the course as one for biology majors. Because they are often required as prerequisites for nursing programs and as part of healthcare-related degrees and certificates, I also deemed courses with variations on the following names as healthcare-related courses: human anatomy, human physiology, human anatomy and physiology, medical terminology, introduction to pharmacology, and microbiology.

\section{Data Analysis}

I calculated descriptive statistics about the enrollment size of the institutions in my sample, including the mean and range of FTE students. I examined the relationship between institutional size and online offerings for Fall 2015 and Spring 2016 separately by grouping the institutions sampled during each time period into four groups based on their 2012-2013 FTE student enrollment data (<1500; 1500-4999; 5000-9999; and $>10,000$ FTE undergraduate students) and then conducted $2 \times 4$ chi-square analyses to determine whether the proportions of institutions in each group, with and without online offerings, were the same. I then examined institutional size trends more closely for all of the institutions sampled that had online offerings in biology in Fall of 2015 and Spring of 2016. To determine whether there is a relationship between institution size and the number of all biology courses and sections offered (face-to-face, hybrid, and online), I conducted two simple linear regressions with size of the institution as the independent variable and number of biology courses and sections as dependent variables. I also conducted three simple linear regression analyses using institutional enrollment numbers as the independent variable and number of unique biology courses offered online (as an indication of online course variety), percent of total biology courses offered online (as an indication of the extent of online course offerings), and percent of total biology sections offered online (as an indication of online course availability) as dependent variables.

To examine relationships between the type of academic institution and online offerings, I counted the number of institutions in each of my three categories that offered at least one online or hybrid course and the number that offered only faceto-face biology courses. I then conducted chi-square tests on the Fall 2015 and Spring 2016 data separately to compare the proportions of 2-year, 4-year public, and 4-year private institutions that offered at least one online or hybrid biology course. To compare difference in online course variety, extent of online course offerings, and availability of online sections, I counted the number of online courses and calculated the percent of online courses and percent of online sections offered at 2-year, 4-year public, and 4-year private institutions. Because the Fall 2015 and Spring 2016 data failed two of the assumptions of the analysis of variance test-homogeneity of variance and normal 
distribution of data-I used the Kruskal-Wallis test to compare their distributions between institution types. When the Kruskal-Wallis generated a $p$ value $<0.05$, I conducted pairwise comparisons between all groups, using Wilcoxon rank-sum tests with Bonferroni-corrected $p$ values as my critical value. I also conducted Wilcoxon rank-sum tests to determine whether there were differences in the number of courses, percent of courses, and percent of sections offered online at 2-year public institutions in Fall 2015 versus Spring 2016 and repeated these analyses separately for 4-year public and private institutions.

To analyze the course data, I pooled all of the course-level data collected from the three types of institutions over the academic year. I then counted the number of courses offered fully online, only as hybrids, for biology majors, for nonmajors, for healthcare professionals, with laboratories, and without laboratories and calculated the associated proportions. Finally, I calculated the proportion of courses that fit into each of the following categories: hybrid lab courses for majors, hybrid lab courses for nonmajors, hybrid nonlaboratory course for majors, hybrid nonlaboratory course for nonmajors, online lab courses for majors, online lab courses for nonmajors, online nonlaboratory courses for majors, and online nonlaboratory courses for nonmajors.

I used R (R Core Team, 2015) to calculate the summary and inferential statistics and Microsoft Excel to generate figures. I used alpha $=0.05$ as the critical $p$ value for all statistical tests and have reported means $\pm 1 \mathrm{SE}$.

\section{RESULTS}

I surveyed the course schedules of 96 American institutions of higher education, 48 from Fall 2015 and 48 from Spring 2016. There were many more 4-year private institutions that did not meet my sampling criteria. For example, I had to examine the Spring 2016 offerings of 33 4-year private institutions to find 16 that had offerings in biology or biological sciences and displayed their course schedule online. In contrast, I was able to find 16 suitable 2- and 4-year public institutions by sampling 17 and 19 institutions, respectively. Of 69 institutions I randomly selected for sampling in Spring 2016, 5.8\% were excluded, because their schedules were not available online, while closer to $25 \%$ were excluded, because they did not offer biology courses (e.g., seminaries and schools of art and design). The institutions sampled ranged in size from 66 to more than 32,000 FTE students in 2012-13, with the mean size of institutions sampled being $5271 \pm 886$ and $5115 \pm 738$ FTE students in the Fall and Spring, respectively.

I found no evidence of relationships between an institution's enrollment size and its online offerings. Enrollment data were unavailable for one of the institutions I sampled, thus the chisquare analyses described below include 47 institutions sampled in Fall and 48 sampled in Spring. The percentage of institutions with less than 1500, between 1500 and 4999, between 5000 and 9999, and more than 10,000 FTE students offering at least one online biology course varied between 38.46 and $66.67 \%$ in the Fall semester and 38.46 and $80.00 \%$ in the Spring semester (Figure 1). Chi-square analyses showed, however, that there was no relationship between the size class of an institution and whether that institution offered any online courses in biology in the Fall $\left(\chi^{2}=1.73 ; p=0.63 ; d f=3\right)$ or Spring $\left(\chi^{2}=3.90 ; p=0.27 ; d f=3\right)$. Of the 50 institutions in my

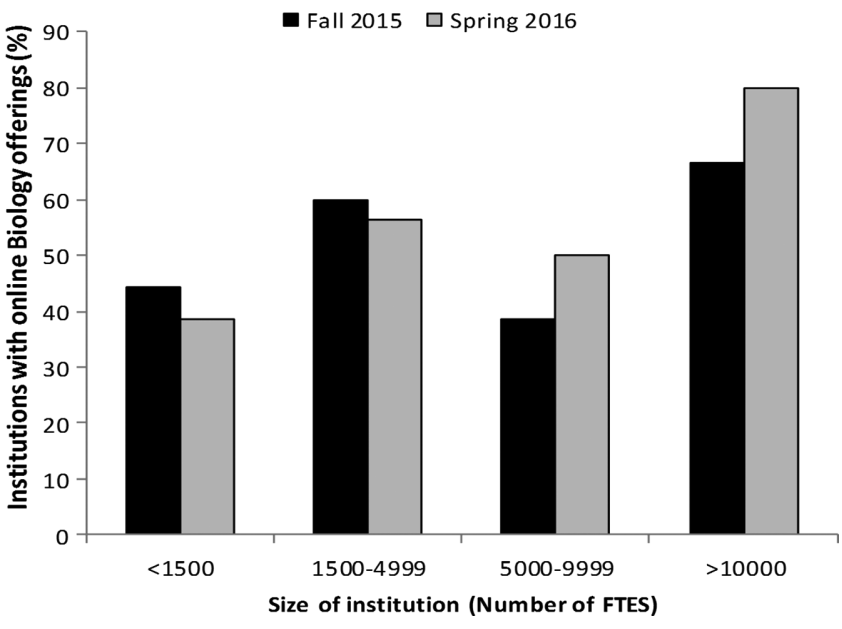

FIGURE 1. Percent of academic institutions offering at least one online or hybrid course in biology during the Fall of 2015 and Spring of 2016 by institution size class, determined by the number of FTE students.

combined academic year sample that offered at least one online or hybrid course in biology, I found the expected positive relationships between the number of FTE students and total number of biology courses $\left(R^{2}=0.26 ; p<0.001\right)$ and sections $\left(R^{2}=\right.$ $0.44 ; p<0.001$ ) offered. However, among the same 50 institutions, there was no statistically significant relationship between the number of FTE students and 1) the number of online or hybrid biology courses $\left(R^{2}=0.001 ; p=0.80\right)$ and sections $\left(R^{2}=\right.$ $0.03 ; p=0.27) ; 2$ ) the percent of their biology courses offered fully online or hybrid $\left(R^{2}=0.02 ; p=0.27\right)$; and (3) the percent of their biology sections offered online or hybrid $\left(R^{2}=0.05\right.$; $p=0.11$ ).

I did, however, find strong differences between the online offerings at 2-year public, 4-year public, and 4-year private schools. In Fall of 2015, a high proportion, nearly 0.9 of 2 -year public institutions surveyed, offered at least one fully online or hybrid class in biology. The same was true of fewer than half of 4-year public and one-quarter of 4-year private institutions (Figure 2). In the Spring of 2016, the results were similar, with more than 0.8 of the 2 -year public institutions offering online biology courses, while the same was true of fewer than half of the 4-year institutions surveyed (Figure 2). Chi-square analysis showed a significant difference between these proportions in the Fall $\left(\chi^{2}=13.19 ; p=0.001 ; d f=2\right)$ and Spring $\left(\chi^{2}=8.68\right.$; $p=0.01 ; d f=2)$, indicating strong differences in the availability of online biology course offerings by type of institution.

My results comparing the numbers and percentages of biology courses offered online or hybrid indicate strong differences in the amount and extent of online offerings at the different types of academic institutions analyzed in the Fall of 2015 and Spring of 2016. With the average number of courses offered online at 2-year public, 4-year public, and 4-year private institutions being $3.69 \pm 0.68,0.94 \pm 0.35$, and $0.38 \pm 0.20$ in the Fall and $2.94 \pm 0.67,0.88 \pm 0.30$, and $0.44 \pm 0.18$ in the Spring, respectively (Figure 3), 2-year institutions in my survey offered five times the mean number of online courses offered at 4-year institutions over the academic year. There were significant differences between the distributions of the numbers of courses 


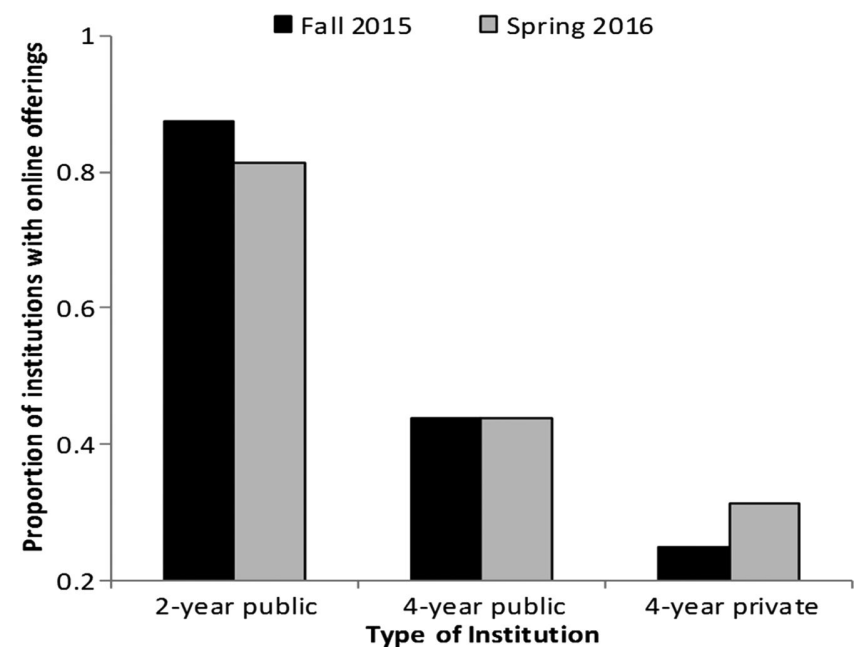

FIGURE 2. Percent of 2-year public, 4-year public, and 4-year private academic institutions offering at least one online or hybrid course in biology during the Fall of 2015 and Spring of 2016.

offered at the different types of institutions surveyed in the Fall (Kruskal-Wallis $\chi^{2}=18.92 ; p<0.001$ ) and Spring (Kruskal-Wallis $\chi^{2}=12.39 ; p=0.002$ ). Pairwise comparisons indicate significant differences in the distribution of numbers of biology online courses offered at 2- and 4-year public (Fall: $W=210 ; p=0.002$; Spring: $W=64.5 ; p=0.01$ ) and at 2 - and 4-year private institutions (Fall: $W=228 ; p<0.001$; Spring: $W=45 ; p=0.001$ ). However, there was no significant difference between the distribution of the numbers of online and hybrid courses offered at 4-year public and 4-year private institutions (Fall: $W=155.5$; $p=0.226$; Spring: $W=106 ; p=0.35$ ). Similarly, I found significant differences between the distributions of the percentages of online and hybrid courses offered at the three types of institutions surveyed (Fall: Kruskal-Wallis $\chi^{2}=21.91 ; d f=2 ; p<$ 0.001; Spring: Kruskal-Wallis $\chi^{2}=15.93 ; d f=2 ; p<0.001$ ). In the Fall and Spring, $43 \pm 8.08 \%$ and $29.01 \pm 6.22 \%$, respectively, of the courses offered at 2-year institutions were offered in an online or hybrid format. These distributions were significantly different from the distributions of percentages of online and hybrid courses offered at 4-year public (Fall: $W=222 ; p<$ 0.001; Spring: $W=46.5 ; p=0.002$ ) and 4-year private institutions (Fall: $W=233$; $p<0.001$; Spring: $W=38 ; p<0.001$ ), which only offered an average of $5.69 \pm 1.88 \%$ and $2.78 \pm$ $0.97 \%$, respectively, of their courses online over the academic year (Figure 3). There was no significant difference between the distributions of the percentage of courses offered at 4-year public and private institutions in the Fall $(W=152 ; p=0.296)$ or Spring $(W=119 ; p=0.71)$.

My results comparing the percent of sections offered online or hybrid give an indication of how the availability of online options differ at the types of academic institutions surveyed. I found significant differences between the distributions of percentages of sections that were offered online and hybrid at the three types of institutions surveyed in the Fall (Kruskal-Wallis $\left.\chi^{2}=19.861 ; d f=2 ; p<0.001\right)$ and Spring (Kruskal-Wallis $\chi^{2}=$ $10.57 ; d f=2 ; p=0.005)$. In the Fall, only $3.35 \pm 1.48 \%$ and $1.37 \pm 0.81 \%$ of the sections offered at 4-year public and private institutions were online or hybrid, and the distributions
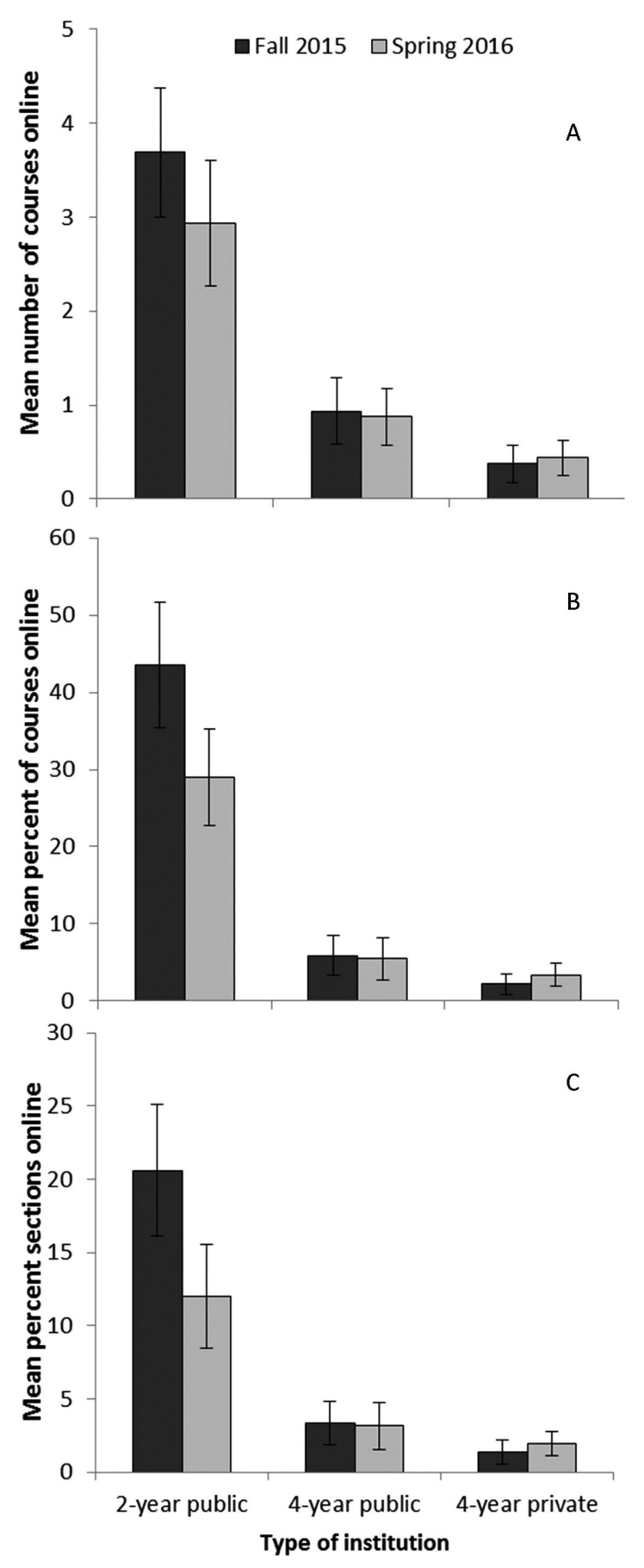

FIGURE 3. Mean number of courses (A), mean percent of courses (B), and mean percent of sections (C) offered at 2-year public, 4-year public, and 4-year private institutions that were online and hybrid during the Fall of 2015 and Spring of 2016. Error bars represent SE.

did not differ significantly ( $W=152 ; p=0.296$; Figure 3 ), with similar results in the Spring $(W=118.5 ; p=0.70)$. However, over the academic year, $16.32 \pm 2.91 \%$ of sections were offered as online or hybrid at 2-year institutions, and the distribution of data differed significantly from that of 4-year public (Fall: $W=$ 216; $p<0.001$; Spring: $W=61 ; p=0.01$ ) and private institutions (Fall: $W=229 ; p<0.001$; Spring: $W=55.5 ; p=0.005$ ). 


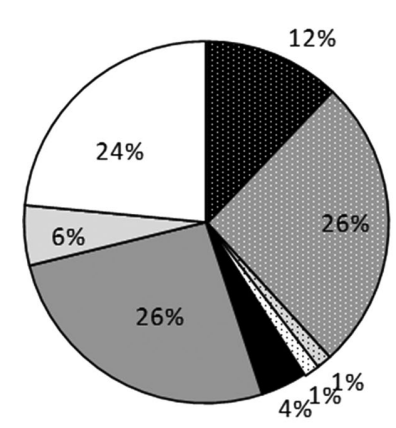

Hybrid, lab courses for majors

$\square$ Hybrid, lab courses for non-majors

Hybrid, non-lab course for majors

․․․ Hybrid, non-lab course for non-majors

Online, lab courses for majors

$\square$ Online, lab courses for non-majors

$\square$ Online, non-lab courses for majors

$\square$ Online, non-lab courses for nonmajors

FIGURE 4. Percent of online biology courses offered over the 2015-2016 academic year (Fall and Spring semesters or Fall, Winter, and Spring quarters) by modality (hybrid vs. fully online), laboratory status (present vs. absent), and intended audience (biology majors vs. nonmajors).

There was no significant variation in the online biology offerings in Fall 2015 and Spring 2016. Specifically, I found no differences in the distribution of the number of courses, percent of courses, and percent of sections offered online and hybrid by 2-year institutions $(W=150.5 ; p=0.40 ; W=161.5 ; p=0.21$; and $W=167 ; p=0.15$, respectively), 4-year public institutions $(W=129 ; p=0.98 ; W=129.5 ; p=0.97 ;$ and $W=124.5 ; p=$ 0.90 , respectively), and 4-year private institutions ( $W=119.5$; $p=0.70 ; W=114.5 ; p=0.54$; and $W=119 ; p=0.67$, respectively) in the Fall of 2015 versus the Spring of 2016. This indicates consistency in biology online offerings across the academic year.

To determine which kinds of biology courses are being offered online in an academic year, I examined the 149 online and hybrid courses offered in the Fall 2015 and Spring of 2016 in my random sample. A larger percentage of the courses in my sample were offered in a fully online format, 59.06\%, compared with $40.94 \%$ that were only offered as hybrid courses (Figure 4). While $22.82 \%$ of the courses surveyed served the institution's biology majors, $77.18 \%$ were not part of the biology major and are therefore referred to as nonmajors courses (Figure 4). More than $35 \%$ of the courses I surveyed were healthcare-related courses, and more than $90 \%$ of these were nonmajors courses. A high percentage of the hybrid and online courses surveyed were laboratory courses, $68.46 \%$, while the remaining $31.54 \%$ did not include a laboratory.

Finally, I quantified all three of the course attributes noted above: whether the course was fully online or hybrid; laboratory or nonlaboratory; and intended for biology majors or nonmajors. The three largest categories of courses were all intended for nonmajors. These include fully online laboratory courses and hybrid laboratory courses, which were each $26.17 \%$ of my sample, followed by fully online nonlaboratory courses, which were $23.49 \%$ of my sample. Hybrid, laboratory courses for majors were $12.08 \%$ of the courses surveyed over the academic year, and they were nearly three times more common than fully online courses with laboratories for majors, which were $4.08 \%$ of my sample. Fully online, nonlaboratory courses for majors were slightly more common, $5.37 \%$, than the fully online laboratory courses for majors. There were few hybrid, nonlaboratory courses for biology majors (1.34\%) and nonmajors $(1.34 \%)$ in my sample (Figure 4).

\section{DISCUSSION}

\section{Institution Size and Online Biology Offerings}

Despite strong positive relationships between the size of an institution and the total numbers of biology courses and sections offered, indicating that larger institutions are serving more students with more courses and sections, I found no evidence of positive relationships between the size of an institution and the diversity and availability of its online offerings in biology. These findings differ from what others have found about online offerings and institution size in general. Typically, there is a positive relationship between institutional size and the likelihood of offering at least one online course in any discipline (Parasad and Lewis, 2008). This pattern has been attributed to resource discrepancies (Allen and Seaman, 2014), with large institutions having more resources to provide and support online courses than small institutions.

This pattern may not hold true for biology courses, because other obstacles are preventing biology departments from moving forward with online courses. Faculty resistance to teaching online is a commonly cited obstacle. Faculty report resistance to teaching online for a variety of reasons, including their perceptions that teaching online is more work than teaching face-toface courses (Berge, 1998; Bolliger and Wasilik, 2009; Seaman, 2009) and their lack of technological expertise (Berge, 1998; Bower, 2001; Kennepohl and Shaw, 2010). Biology faculty may be particularly resistant to developing online laboratory courses, because such courses require testing a new suite of laboratory activities and related technologies that would further increase the initial workload. Additionally, it is possible that online laboratories may cause administrators to fear liability issues, thus prompting institutions to direct their efforts toward pursuing online courses in other disciplines.

The random variation in online offerings relative to institution size may also indicate that biology departments have different motivations for offering online courses than other departments. Insufficient classroom space has compelled some institutions to pursue online offerings (Howell et al., 2003; Picciano, 2006; Brown, 2011). This factor may play a larger role in the decision to offer science courses online, because laboratory classrooms have more specialized safety and equipment requirements (National Research Council, 2006), making them less interchangeable with other spaces. Additionally, laboratory classrooms are more costly to build and maintain (National Research Council, 2006). When classroom shortages are limiting enrollment growth, the addition of other kinds of classrooms is likely more efficient. Furthermore, traditional laboratory sections are expensive to run, and institutions can cut costs by offering laboratories online (Powell et al., 2002). Thus, laboratory space and limiting course budgets may be motivating biology departments with fewer resources to offer courses online, thereby obscuring the expected positive relationship between the size of the institution and availability of online offerings. This could mean many biology faculty are teaching online without adequate technological support and training. This is a common complaint among online instructors (Berge, 1998; Seaman, 2009) that could hinder online course and program success (Howell et al., 2004). 


\section{Institution Type and Online Biology Offerings}

I found significantly higher availability and diversity of online courses in biology at 2-year public compared with 4-year public and private institutions (Figures 2 and 3). There was, however, no difference between the availability and diversity of biology online offerings at 4-year public and 4-year private institutions. These findings differ from Allen and Seaman's (2015) findings, which showed that, while only $65 \%$ of 4 -year private colleges have any online offerings, more than $90 \%$ of 4 -year public and 2 -year public colleges offer online offerings. Surprisingly, given the reduced involvement of STEM students in online education, I found the percentage of 2-year public colleges offering online courses in biology was similar to the percentage of 2 -year public colleges with at least one online course offering in general (Allen and Seaman, 2015). I found, however, that $~ 50 \%$ fewer 4-year public and 35\% fewer 4-year private institutions offer online biology courses compared with the percentages of those types of colleges with online courses in general.

The large amount of online biology course diversity and availability at 2-year public colleges is likely a response to high demand from students. Two-year public colleges have five times the number of students age 24 and older than 4-year colleges do (Alderman, 2005). Older students, ages 35-55, are known to prefer online learning (Garrett, 2007). Two-year public college students are also more likely to come from low-income families, have dependent children, and declare themselves financially independent for financial aid purposes. Thus, $79 \%$ of 2-year public college students work an average of 32 hours per week while enrolled, and 41\% work full-time (Horn and Nevill, 2006). The flexibility of asynchronous learning in an online format appeals to students who also face the demands of raising children and/or working. Furthermore, 2-year public college students are less likely to be enrolled fulltime (Horn and Nevill, 2006) and in residence on campus. Thus, the online format may save them time and money associated with commuting.

Sixty-four percent of the 4-year institutions I sampled had no online biology offerings. The reduced number of biology online offerings at 4-year institutions is aligned with other reports of fewer offerings in the sciences compared with other disciplines (Allen and Seaman, 2008; Radford 2011). Nonetheless, it indicates a possible barrier for students preferring or requiring online education who are pursuing bachelor's degrees at American colleges and universities.

I failed to find any significant differences between the diversity and extent of online biology offerings at 2-year public, 4-year public, and 4-year private institutions in Fall of 2015 versus Spring of 2016, indicating consistency in online biology options over the academic year. It is possible, however, that institutions offer more online courses in the Summer term to serve their students who are only in residence on campus in the Fall and Spring; I discovered several 4-year private institutions that only offer online courses in the Summer term, although none of the courses were biology courses. The lack of data about Summer offerings is a limitation of this research.

\section{Types of Courses}

I found more online biology courses for nonmajors (Figure 4). Compared with developing an online biology program for majors, offering one or two nonmajors courses requires fewer resources. Furthermore, because of added convenience and flexibility, online nonmajors courses may better compete with courses from other science departments for general education students. A comparison of the supply of online biology general education offerings to those of other science disciplines remains a research gap.

The high number of nonmajors courses may also relate to faculty members' commonly held perception of the reduced quality of online courses (Berge 1998; Bower, 2001; Seaman, 2009). This perception, which is more common among faculty and administrators with little experience in online education (Seaman, 2009; Allen and Seaman, 2013), exists despite strong evidence to the contrary, including the results of two large meta-analyses that reviewed 51 (Means et al., 2009) and 125 studies (Shachar and Neumann, 2010). These studies compared outcomes in face-to-face versus hybrid or online courses and found that, on average, student performance was better in online or hybrid compared with face-to-face courses. Evidence also indicates that online course quality has improved through time (Shachar and Neumann, 2010; Brinson, 2015), likely as a result of the adoption of effective online teaching practices and improved technology. This disjunction between documented perceptions of online course quality and the related scientific research highlights the need for more faculty training and professional development in online education. Yet because general education biology courses are not laying a foundation of discipline-specific knowledge and skills for future biologists, biology faculty who still question the quality of online courses may be more comfortable if online courses are for general education students.

Additionally, a large portion of the online biology nonmajors courses in my survey were courses that serve students completing healthcare program prerequisites or degree requirements indicating that these students have more online options than other populations. This finding also helps explain the higher proportion of courses for nonmajors in my sample and is aligned with high interest in online learning among students pursuing postsecondary degrees in healthcare-related fields (Garrett, 2007). Furthermore, since nearly $90 \%$ of the online healthcare-related courses in my sample were offered at 2-year public colleges, the high number of health-care related courses also helps explain the high number of online offerings in biology at 2-year public institutions. In 2012-2013, 21\% of all associate's degrees awarded in the United States were healthcare and related degrees; the number of students earning these degrees was 50 times higher than the number of students earning degrees in biology (NCES, 2014). Thus, students pursuing these degrees make up a large portion of biology enrollments at 2-year colleges, and the faculty and administrators at these institutions seem to be responding to their desire to complete their courses online.

I found equal proportions of online and hybrid laboratory courses offered for nonmajors, but the proportion of fully online laboratory courses compared with hybrid laboratory courses was not quite one-third for biology majors (Figure 4). This may indicate that some biology departments are hesitant to offer fully online laboratory courses for biology majors despite evidence of high demand for fully online laboratory science courses from science majors (Kennepohl, 2007), further demonstrating limited online course opportunities for biology majors. 
Online laboratories may be offered more frequently for nonmajors, because instructors are more willing to use online or at-home hands-on activities in nonmajors courses. In some cases, these activities could have added benefits for nonmajors. For example, kitchen laboratories may help nonmajors students find relevance in the content (Reeves and Kimbrough, 2004). On the other hand, online laboratory courses could pose transferability issues that would be heightened for biology majors due to the number of laboratory science courses they must complete. When transferring in courses, some institutions will not count laboratory courses lacking traditional, face-to-face laboratories as equivalent to their face-to-face courses (Brewer et al., 2013). Although this issue may be resolved in time as online laboratory courses become more common, transferability of laboratory courses is currently a serious concern that online science course instructors, counselors, and potential students should carefully consider.

Additionally, some authors believe that simulated or at-home alternatives to the traditional laboratories are not sophisticated enough to train future scientists (Lyall and Patti, 2010). Thus, reduced numbers of fully online laboratory courses for biology majors may also reflect fears about the quality of online laboratory courses. However, a growing body of evidence to the contrary should alleviate these concerns. For example, those studying learning outcomes in face-to-face versus online biology laboratory activities have found that online students can achieve similar learning outcomes (Johnson, 2002; Gilman, 2006; Lunsford and Bolton, 2006). Even more convincing, a recent meta-analysis reported that $89 \%$ of studies comparing learning outcomes in traditional versus virtual and/or remote laboratories found equal learning outcomes, while $65 \%$ reported higher learning outcomes in nontraditional laboratories (Brinson, 2015). Other researchers have documented additional educational benefits of online laboratory science courses, including 1) higher final course grades (Reeves and Kimbrough, 2004; Lyall and Patti, 2010); 2) deeper learning, because students are forced to work independently through issues they encounter doing laboratory activities at home (Jeschofnig and Jeschofnig, 2011); and 3) the ability to transcend time and space limitations imposed by traditional laboratories (Forinash and Wiseman, 2001). Carefully designed online laboratory courses can be effective, and instructors interested in developing an online laboratory course have many successful models to reference (e.g., Reeves and Kimbrough, 2004; Mickle and Aune, 2008; Reuter, 2009; Brown, 2011; Barbeau et al., 2013). Thus, online laboratory courses should be considered, even for biology majors.

Hybrid courses, which were more commonly offered to biology majors than fully online laboratory courses, require students to complete face-to-face laboratories and are a suitable compromise in some cases. Some departments have tried to make hybrid science courses more convenient for their students by limiting laboratory time to a small number of extended laboratory periods that often meet on weekends (Lyall and Patti, 2010; Jeschofnig and Jeschofnig, 2011; Brewer et al., 2013). This arrangement makes completing laboratory courses possible for many students who are place-bound, working, and/or balancing education with family life. However, concentrating laboratory time can mean laboratory topics are not synced with the rest of the course, and extended laboratory periods may be exhausting for students (Jeschofnig and Jeschofnig, 2011). This may limit their effectiveness, although a comparison of this specific style of hybrid laboratory course with others has not been documented. Furthermore, even with a reduced number of face-to-face meetings, some students will still be unable to attend. Thus, hybrid courses with face-to-face laboratories can be useful to some but not all students.

Finally, I was surprised to find such a small number of nonlaboratory courses offered in the hybrid form, despite evidence that blending online and face-to-face instruction can be beneficial. Advantages of hybrid courses include higher learning outcomes (Dziuban et al., 2004; Vaughan, 2007; Means et al., 2009) and lower withdrawal rates than fully online courses (Dziuban et al., 2004). Additionally, student demand for hybrid courses is high (Dziuban et al., 2004), and many attribute this to their desire for face-to-face interaction and more flexible scheduling (Vaughan, 2007). Faculty who teach hybrid courses report having enhanced student-teacher interactions (Riffell and Sibley, 2004b) and improved student engagement in the learning process (Vaughan, 2007). Studies focused specifically on comparing course outcomes in hybrid versus face-to-face science courses have found that 1) online assignments in hybrid courses are equivalent to or more effective than passive lectures (Riffell and Sibley, 2004b); 2) video lectures can be as effective at teaching complicated concepts as face-to-face lectures (Lents and Cifuentes, 2009); 3) participation and attendance can be higher in hybrid courses (Riffell and Sibley, 2004a); and 4) learning outcomes can be higher than or equal to those in face-to-face courses (Riffell and Sibley, 2004b; White and Sykes, 2012). Hybrid courses can have institutional benefits as well. In addition to reducing institutional operating costs (Dziuban et al. 2004), hybrid courses have been described as an effective and low-risk strategy that positions institutions for future technological developments (Garrison and Kanuka, 2004). Thus, institutions, faculty, and students have much to gain by increasing offerings of hybrid biology courses.

\section{CONCLUSIONS}

This research has described the current landscape of online offerings in biology. This baseline illustrates that, while some populations, including nonmajors completing prerequisites for healthcare-related programs or completing their science general education requirements at 2-year public colleges, are well served by the current online offerings, others are not. Online options at 4-year institutions were limited, and students majoring in biology had few online course options, especially online laboratory courses, at all types of institutions studied. Addressing these deficiencies would create more opportunities for students requiring or preferring online education to study biology while possibly promoting student diversity and boosting departmental enrollment. This research also identifies some potential barriers that are limiting the online offerings in biology.

The following recommendations are for biology departments with few or no online offerings and are intended to help overcome barriers and increase student access to online learning opportunities in biology:

- Provide faculty with professional development training focused on successful course redesign models (e.g., Twigg, 2003), best practices in online instruction (e.g., Newlin and 
Wang, 2002; Fish and Wickersham, 2009; Berge 2011; McGee and Reis, 2012), and related technologies.

- Develop incentives and other institutional mechanisms of support for faculty teaching online that can help alleviate the initially high workload involved with course development.

- Offer at least one general education hybrid or fully online course. This would give more students at the institution an opportunity to learn about biology and may boost departmental enrollment.

- Offer healthcare professional-degree prerequisite courses online, as these courses seem to be in particularly high demand from students.

- Develop online course opportunities for biology majors. Course transferability issues could be minimized by selecting the hybrid format for laboratory courses or by developing fully online nonlaboratory courses for majors.

Increasing online offerings in biology can make biology content accessible to more students while benefiting biology departments and institutions. At a time when we need to be increasing science literacy and training more scientists, online biology education is crucial.

\section{ACKNOWLEDGMENTS}

I thank College of the Siskiyous for providing sabbatical leave allowing me to conduct this and other research about online education. Additionally, the manuscript was greatly improved by feedback from D. Clarke, W. Hirt, S. Lishawa, M. White, and two anonymous reviewers.

\section{REFERENCES}

Alderman C (2005). Moving into Town and Moving On: The Community College in the Lives of Traditional-Aged Students, Washington, DC: U.S. Department of Education.

Allen IE, Seaman J (2008). Staying the Course: Online Education in the United States, 2008, Needham, MA: Sloan Consortium.

Allen IE, Seaman J (2013). Changing Course: Ten Years of Tracking Online Education in the United States, Babson Park, MA: Babson Survey Research Group and Quahog Research Group.

Allen IE, Seaman J (2014). Grade Change: Tracking Online Education in the United States, Babson Park, MA: Babson Survey Research Group and Quahog Research Group.

Allen IE, Seaman J (2015). Grade Level: Tracking Online Education in the United States, Babson Park, MA: Babson Survey Research Group and Quahog Research Group.

Allen IE, Seaman J, Garrett R (2007). Blending in: The Extent and Promise of Blended Education in the United States, Needham, MA: Sloan Consortium.

American Chemical Society (ACS) (2009). ACS Guidelines for Chemistry in Two-Year College Programs, Washington, DC: American Chemical Society.

ACS (2015). Undergraduate Professional Education in Chemistry: ACS Guidelines and Evaluation Procedures for Bachelor's Degree Programs, Washington, DC: American Chemical Society.

Barbeau ML, Johnson M, Gibson C, Rogers KA (2013). The development and assessment of an online microscopic anatomy laboratory course. Anat Sci Educ 6, 242-252.

Berge $Z$ (1998). Barriers to online teaching in post-secondary institutions: can policy changes fix it? J Distance Learn Admin 1. www.westga.edu/ distance/Berge12.html (accessed 22 October 2015).

Berge Z (2011). Pedagogy of online instruction. In: Pedagogical Models: The Discipline of Online Teaching, ed. MF Shaughnessy and S Fulgham, New York: Nova Science, 88-96.
Bolliger D, Wasilik O (2009). Factors influencing faculty satisfaction with online teaching and learning in higher education. Distance Educ 30, 103116.

Bower BL (2001). Distance education: facing the faculty challenge. J Distance Learn Admin 4. www.westga.edu/ distance/ojdla/summer42/ bower42.html (accessed 22 October 2015).

Brewer SE, Cinel B, Harrison M, Mohr C (2013). First year chemistry laboratory courses for distance learners: development and transfer credit acceptance. Int Rev Res Open Distance Learn 14, 488-507.

Brinson JR (2015). Learning outcome achievement in non-traditional (virtual and remote) versus traditional (hands-on) laboratories: a review of empirical research. Comput Educ 87, 218-237.

Brown J (2011). A case study from start to finish: the why and how of placing microbiology completely online at Ocean County College. In: Teaching Lab Science Courses Online: Resources for Best Practices, Tools, and Technology, San Francisco, CA: Jossey-Bass, 147-162.

Dziuban CD, Hartman JL, Moskal PD (2004). Blended learning. ECAR Res Bull 7. www.educause.edu/ecar (accessed 22 March 2016).

Fish WW, Wickhersham LE (2009). Best practices for online instructors: reminders. Q Rev Distance Educ 10, 279-284.

Forinash K, Wiseman R (2001). The viability of distance education science laboratories. THE J 29, 40-45.

Garrett R (2007). Expanding demand for online higher education: surveying prospective students. J Asynchronous Learn Networks 11, 49-53.

Garrison DR, Kanuka H (2004). Blended learning: uncovering its transformative potential in higher education. Internet High Educ 7, 95-105.

Geith C, Vignare K (2008). Access to education with online learning and open educational resources: can they close the gap? J Asynchronous Learn Networks 12, 105-126.

Gilman SL (2006). Do online labs work? An assessment of an online lab on cell division. Am Biol Teach 68, 131-134.

Ginder S, Stearns C (2014). Enrollment in Distance Education Courses by State: Fall 2012 (NCES 2014-023), Washington, DC: U.S. Department of Education.

Horn L, Nevill S (2006). Profile of Undergraduates in U.S. Postsecondary Education Institutions: 2003-04: With a Special Analysis of Community College Students (NCES 2006-184), Washington, DC: U.S. Department of Education.

Howell SL, Saba F, Lindsay NK, Williams PB (2004). Seven strategies for enabling faculty success in distance education. Internet Higher Educ 7, 33-49.

Howell SL, Williams PB, Lindsay NK (2003). Thirty-two trends affecting distance education: an informed foundation for strategic planning. J Distance Learn Admin 6. www.westga.edu/ distance/ojdla/fall63/howell63.html (accessed 7 October 2015).

Jeschofnig L, Jeschofnig P (2011). Teaching Lab Science Courses Online: Resources for Best Practices, Tools, and Technology, San Francisco, CA: Jossey-Bass.

Johnson M (2002). Introductory biology online: assessing outcomes of two student populations. J Coll Sci Teach 31, 312-317.

Kennepohl D (2007). Using home laboratory kits to teach general chemistry. Chem Educ Res Prac 8, 337-346

Kennepohl D, Shaw L (2010). Accessible Elements: Teaching Science Online and at a Distance, Edmonton, Canada: AU Press.

Kim KJ, Bonk CJ (2006). The future of online teaching and learning in higher education: the survey says.... Educause Q 4, 22-30.

Klymkowsky MW (2005). Can nonmajors courses lead to biological literacy? Do majors courses do any better? Cell Biol Educ 4, 196-198.

Lents NH, Cifuentes OE (2009). Web-based learning enhancements: video lectures through voice-over PowerPoint in a majors-level biology course. J Coll Sci Teach 39, 38-46.

Lunsford E, Bolton K (2006). Coming to terms with the online instructional revolution: a success story revealed through action research. Bioscene 32, 12-16

Lyall R, Patti AF (2010). Taking the chemistry experience home: home experiments for kitchen chemistry. In: Accessible Elements: Teaching Science Online and at a Distance, ed. D Kennepohl and L Shaw, Edmonton, Canada: AU Press, 83-108. 
Mayadas FA, Bourne J, Bacsich P (2009). Online education today. Science 323, 85-89.

McGee P, Reis A (2012). Blended course design: a synthesis of best practices J Asynchronous Learn Networks 16, 7-22.

Means B, Toyama Y, Murphy R, Bakia M, Jones K (2009). Evaluation of Evidence-Based Practices in Online Learning: A Meta-Analysis and Review of Online Learning Studies, Washington, DC: U.S. Department of Education.

Mickle JE, Aune PM (2008). Development of a laboratory course in nonmajors general biology for distance education. J Coll Sci Teach 37, 35-39.

Moloney JF, Oakley B (2010). Scaling online education: increasing access to higher education. J Asynchronous Learn Networks 14, 55-70.

National Academies of Science, Engineering, and Medicine (2007). Rising above the Gathering Storm: Energizing and Employing America for a Better Economic Future, Washington, DC: National Academies Press.

National Academies of Science, Engineering, and Medicine (2011). Expanding Underrepresented Minority Participation: Americans Science and Technology Talent at the Crossroads, Washington, DC: National Academies Press.

National Center for Education Statistics (NCES) (2014). Associate's Degrees Conferred by Postsecondary Institutions, by Sex of Student and Discipline Division: 2002-03 through 2012-13. http://nces.ed.gov/programs/ digest/d14/tables/dt14_321.10.asp (accessed 12 November 2015).

NCES (2015). Integrated Post-Secondary Education Data System. http:// nces.ed.gov/ipeds (accessed 7 August 2015).

National Research Council (2006). America's Lab Report: Investigations in High School Science, Washington, DC: National Academies Press.

National Science Teacher's Association (2007). The Integral Role of Laboratory Investigations in Science Instruction. www.nsta.org/about/positions/ laboratory.aspx (accessed 20 October 2015).

Newlin MH, Wang AY (2002). Integrating technology and pedagogy: Web instruction and seven principles of undergraduate education. Teach Psychol 29, 325-330.

Parasad B, Lewis L (2008). Distance Education at Degree-Granting Post-Secondary Institutions: 2006-7 (NCES 2009-044), Washington, DC: U.S. Department of Education.

Peterson's (2015). Peterson's Online Schools. www.petersons.com/ online-schools.aspx (accessed 1 December 2015).

Picciano AG (2006). Blended learning: implications for growth and access. J Asynchronous Learn Networks 10, 95-102.

Powell RM, Anderson H, Van der Spiegel J, Pope DP (2002). Using webbased technology in laboratory instruction to reduce costs. Comput Appl Eng Educ 10, 204-214.
Radford AW (2011). Learning at a Distance: Undergraduate Enrollment in Distance Education Courses and Programs (NCES 2012-0154), Washington, DC: US Department of Education.

Radford AW, Cominole M, Skomsvold P (2015). Demographic and Enrollment Characteristics for Non-traditional Undergraduates: 2011-12 (NCES 2015-025), Washington, DC: U.S. Department of Education.

R Core Team (2015). R: A Language and Environment for Statistical Computing, Vienna, Austria: R Foundation for Statistical Computing, www .R-project.org (accessed 5 December 2015).

Reeves J, Kimbrough D (2004). Solving the laboratory dilemma in distance learning chemistry. J Asynchronous Learn Networks 8, 47-51.

Reuter R (2009). Online versus in the classroom: student success in a handson lab class. Am J Distance Educ 23, 151-162.

Riffell SK, Sibley DF (2004b). Can hybrid course formats increase attendance in undergraduate environmental science courses? J Nat Resour Life Sci Educ 33, 1-5.

Riffell SK, Sibley DF (2004a). Using Web-based instruction to improve large undergraduate biology courses: an evaluation of the hybrid course format. Comput Educ 44, 217-235.

Seaman J (2009). Online Learning as a Strategic Asset, vol. 2: The Paradox of Faculty Voices: Views and Experiences with Online Learning, Washington, DC/Babson Park, MA: Association of Public Land Grant Universities/ Babson Survey Research Group.

Shachar M, Neumann Y (2010). Twenty years of research on the academic performance differences between traditional and distance learning: summative meta-analysis and trend examination. J Online Learn Teach $6,318-334$

Sundberg MD, Dini M (1993). Science majors vs nonmajors: is there a difference? J Coll Sci Teach 22, 299-304.

Twigg CA (2003). Improving learning and reducing costs: new models for online learning. Educause Rev 38, 28-38.

Vaughan N (2007). Perspectives on blended learning in higher education. Int J eLearning 6, 81-94.

White S, Sykes A (2012). Evaluation of a blended learning approach used in an anatomy and physiology module for pre-registration healthcare students. In: Proceedings of eLmL 2012: The Fourth International Conference on Mobile, Hybrid, and On-line Learning. ThinkMind/IARIA, 1-9, www.thinkmind.org/index.php? view $=$ instance $\&$ instance $=\mathrm{eL} \mathrm{mL}+2012$.

Wright RL (2005). Undergraduate biology courses for nonscientists: toward a lived curriculum. Cell Biol Educ 4, 189-195 